\title{
Characterization of the ability of coagulase-negative staphylococci isolated from the milk of Canadian farms to form biofilms
}

\author{
Yannick D. N. Tremblay, ${ }^{\star} \dagger$ Daphnée Lamarche, ${ }^{*}$ Pauline Chever, ${ }^{*}$ Denis Haine, $† \ddagger$ Serge Messier, ${ }^{*} \dagger$ \\ and Mario Jacques ${ }^{*} \dagger^{1}$ \\ *Département de pathologie et microbiologie, Faculté de Médecine Vétérinaire, Université de Montréal, Saint-Hyacinthe, Québec J2S 2M2, \\ Canada \\ †Canadian Bovine Mastitis Research Network, C. P. 5000, St-Hyacinthe, Québec, Canada J2S 7C6 \\ ‡Département de sciences cliniques, Faculté de Médecine Vétérinaire, Université de Montréal, Saint-Hyacinthe, Québec J2S 2M2, Canada
}

\begin{abstract}
Mastitis is the most common and detrimental infection of the mammary gland in dairy cows and has a major economic impact on the production of milk and dairy products. Bacterial mastitis is caused by several pathogens, and the most frequently isolated bacterial species are coagulase-negative staphylocci (CNS). Although CNS are considered minor mastitis pathogens, the importance of CNS has increased over the years. However, the mechanism and factors involved in CNS intramammary infection are poorly studied and defined. Biofilms have been proposed as an important component in the persistence of CNS intramammary infection. Biofilms are defined as a cluster of bacteria enclosed in a self-produced matrix. The objectives of this study were to investigate the ability of CNS to form biofilms. A total of 255 mastitis-associated CNS isolates were investigated using a standard microtiter plate biofilm assay. The biofilms of some isolates were also observed by using confocal microscopy. The presence of biofilm-associated genes icaA, bap, aap, embP, $f b e$, and atlE was determined by PCR in the 255 isolates. The 5 dominant species assayed were Staphylococcus chromogenes $(\mathrm{n}=111)$, Staphylococcus simulans ( $\mathrm{n}$ $=53)$, Staphylococcus xylosus $(\mathrm{n}=25)$, Staphylococcus haemolyticus $(\mathrm{n}=15)$, and Staphylococcus epidermidis $(\mathrm{n}=13)$, and these represented $85 \%$ of the isolates. The data gathered were analyzed to identify significant links with the data deposited in the Canadian Bovine Mastitis Research Network database. Overall, Staph. xylosus is the species with the strongest ability to form biofilm, and Staph. epidermidis is the species with the lowest ability to form biofilm. Regardless of the species, the presence of $i c a A$, bap, or the combination of multiple genes was associated with a greater ability to form biofilm. A strong relationship between the strength of
\end{abstract}

Received June 1, 2012.

Accepted September 20, 2012.

${ }^{1}$ Corresponding author: mario.jacques@umontreal.ca a biofilm and days in milk was also noted, and CNS isolated later in the lactation cycle appeared to have a greater ability to form biofilm than those isolated earlier in the lactation cycle. In conclusion, Staph. xylosus is the species with the strongest biofilm formation ability. Furthermore, days in milk and gene combinations are predicted to be the variables with the strongest effect on biofilm formation by CNS.

Key words: mastitis, coagulase-negative staphylococci, biofilm, day in milk

\section{INTRODUCTION}

Mastitis is characterized by an inflammatory response caused by the invasion of the mammary gland via the teat orifice by pathogens. Intramammary infection resulting in mastitis can manifest in subclinical (no visual symptoms) or clinical mastitis (local and systemic symptoms). For dairy cows, mastitis is the most common and detrimental disease, having a major economic impact on the production of milk and dairy products. For clinical purposes, an IMI is defined by the presence of bacteria or elevated SCC for quarter or composite samples. However, no international consensus for the definition of an IMI exists (Andersen et al., 2010). Recently, several definitions were evaluated, and it was concluded that the choice of an IMI definition is dependent on the objectives of the study or control program for which the samples are collected (Dohoo et al., 2011). Several bacterial species are considered major mastitis pathogens, including Streptococcus uberis, Staphylococcus aureus, and Escherichia coli.

Coagulase-negative staphylococci are the bacteria most frequently isolated from IMI (Tenhagen et al., 2006; Pyörälä and Taponen, 2009; Sampimon et al., 2009). However, CNS have traditionally been considered a minor mastitis-causing pathogen. Twelve CNS species have been isolated from bovine milk samples, but the prevalent CNS species reported in IMI are Staphylococcus chromogenes and Staphylococcus simulans (Rajala-Schultz et al., 2006; Taponen et al., 2006; 
Pyörälä and Taponen, 2009; Piessens et al., 2011; Supré et al., 2011). Mastitis associated with CNS infections is often subclinical or mild. During lactation, CNS infections may result in an increased milk SCC, which decreases the milk quality and, consequently, results in economic losses. In recent years, the prevalence of CNS-associated IMI has increased in several regions of the globe (Pyörälä and Taponen 2009). Coagulasenegative staphylococci are considered by some an emerging mastitis pathogen (Pyörälä and Taponen, 2009). With regard to a mastitis diagnosis, CNS are not usually identified at the species level and are treated as a uniform group. However, recent research has indicated that some species might be more clinically relevant than others (Supré et al., 2011; Piessens et al., 2011, 2012). Despite the emergence of CNS as pathogens, the knowledge regarding their virulence and associated mechanisms is limited, but biofilm formation has been proposed as an important virulence factor of CNS, especially with regard to the persistence of CNS IMI (Simojoki et al., 2012). Biofilm formation has also been proposed as an important virulence factor for other mastitis pathogens, including Staph. aureus, E. coli, and Strep. uberis (Melchior, 2011).

Biofilms are defined as structured communities of bacterial cells enclosed in a self-produced matrix attached to biotic or abiotic surfaces (Costerton et al., 1999). The ability to form biofilms is considered a universal trait of microorganisms. Furthermore, biofilms offer protection against hostile environments, such as the immune response and bactericidal concentrations of antibiotics or disinfectants. In several bacterial pathogens, biofilm formation is important for virulence; however, the role of biofilms as a virulence factor in veterinary pathogens has been poorly studied (Jacques et al., 2010). Biofilm formation in staphylococcal species is associated with several factors, such as the intracellular adhesion locus (icaABCD), which encodes the proteins responsible for the synthesis of poly- $N$-acetyl glucosamine (PNAG; Mack et al., 1996), the biofilm-associated protein Bap (Cucarella et al., 2004), the accumulation-associated protein Aap (Hussain et al., 1997; Rohde et al., 2005), the fibrinogen adhesin Fbe (Nilsson et al., 1998), the fibronectin adhesin EmbP (Christner et al. 2010), and the bifunctional adhesin and autolysin AtlE (Heilmann et al., 1997).

The Canadian Bovine Mastitis Research Network (CBMRN) is an organization that spearheaded a data collection platform for a single national-level longitudinal cohort for mastitis research. The platform consists of a National Cohort of Dairy Farms (NCDF), Mastitis Laboratory Network, and Mastitis Pathogen Culture Collection (MPCC). The characteristics of the herds and the data collection process were described previously (Reyher et al., 2011). Briefly, health data, production data, and milk samples were collected from the NCDF, milk samples were processed for SCC and bacteriology purposes by the Mastitis Laboratory Network, and bacteria isolated from milk samples were conserved in the MPCC. Furthermore, a small sample of the CNS of the MPCC were speciated based on their rpoB gene sequence. Almost $50 \%$ of the CNS were Staph. chromogenes and the other CNS were Staph. simulans (24.0\%), Staphylococcus xylosus (8.8\%), Staphylococcus haemolyticus (4.9\%), and 16 other species (Dufour et al., 2012; J. R. Middleton, University of Missouri, Columbia, personal communication).

The objectives of this study were to investigate the biofilm-forming ability of CNS isolates from the MPCC, determine the frequency of biofilm-associated genes among these CNS, and, using the data from the NCDF, determine whether biofilm formation is associated with any factors such as SCC, DIM, and lactation number.

\section{MATERIALS AND METHODS}

\section{Bacterial Strains and Growth Conditions}

Coagulase-negative staphylococci isolates were obtained from the MPCC, which is managed by the CBMRN (St-Hyacinthe, Québec, Canada; Reyher et al., 2011). A total of 255 isolates were randomly and blindly selected from 1,049 CNS isolates that were identified at the species level. Coagulase-negative staphylococci were routinely cultured on brain-heart infusion broth (BHI) agar and incubated for $24 \mathrm{~h}$ at $37^{\circ} \mathrm{C}$.

\section{Microtiter Biofilm Assay}

Biofilms were cultured in 96-well microtiter plates as described by Mitchell et al. (2010), with some modifications. Briefly, colonies from a 16-h BHI agar plate were suspended into fresh BHI supplemented with glucose $(0.25 \% \mathrm{wt} / \mathrm{vol})$ to a $0.5 \mathrm{McF}$ arland standard. A volume $(200 \mu \mathrm{L})$ of this inoculum was transferred into 3 wells, and the microtiter plate (Corning Costar no. 3595) was incubated at $37^{\circ} \mathrm{C}$. After a 24 -h incubation, the liquid medium was removed using a vacuum, and the planktonic cells were removed by washing the wells three times with PBS. The biofilms were air-dried and then stained with $0.1 \%$ (wt/vol) safranin for $10 \mathrm{~min}$. The biofilms were washed once with distilled water and then dried at $37^{\circ} \mathrm{C}$ for $15 \mathrm{~min}$. The stain was then released with $200 \mu \mathrm{L}$ of the destaining solution $[50 \%$ ( $\mathrm{vol} / \mathrm{vol}$ ) ethanol, $50 \%$ (vol/vol) glacial acetic acid], and the amount of released stain was quantified by measuring the absorbance at $490 \mathrm{~nm}\left(\mathbf{A}_{\mathbf{4 9 0}}\right)$ with a microplate reader. Staphylococcus epidermidis strain ATCC 35984 
Table 1. Polymerase chain reaction primers used in this study

\begin{tabular}{|c|c|c|c|c|}
\hline Name $^{1}$ & Primer sequence & Description & $\begin{array}{l}\text { Length of } \\
\text { amplicon (bp) }\end{array}$ & Reference \\
\hline icaFSe & 5'-CTGTTTCATGGAAACTCC-3' & \multirow[t]{2}{*}{$i c a A$} & \multirow[t]{2}{*}{200} & \multirow[t]{2}{*}{ Rohde et al. (2007) } \\
\hline icaRSe & 5'-TCGATGCGATTTGTTCAAACA T-3' & & & \\
\hline aapR1 & 5'-AGTTGGCGGTATATCTATTGTA-3' & aap & 289 & Rohde et al. (2005) \\
\hline applongF & 5'-GATTTAGATGGTGCA ACATTGACAT-3' & $\begin{array}{l}\text { Variable region } \\
\text { of aap }\end{array}$ & Variable & Rohde et al. (2005) \\
\hline sasp-7c & 5'-GCTGTTGAAGTTAATACTGTACCTGC-3' & bap & 900 & Cucarella et al. (2004) \\
\hline fbeF & 5'-CTACAAGTTCAGGTCAAGGACAAGG-3' & \multirow[t]{2}{*}{ fbe } & \multirow[t]{2}{*}{273} & \multirow[t]{2}{*}{ Rohde et al. (2007) } \\
\hline fbeR & 5'-GCGTCGGCGTATATCCTTCAG-3' & & & \\
\hline atleF & 5'-CAACTGCTCAACCGAGAACA-3' & \multirow[t]{2}{*}{ atle } & \multirow[t]{2}{*}{682} & \multirow[t]{2}{*}{ Rohde et al. (2007) } \\
\hline atlER & 5'-TTTGTAGATGTTGTGCCCCA-3' & & & \\
\hline embPF & 5'-AGCGGTACAAATGTCAAT-3' & \multirow[t]{2}{*}{$e m b P$} & \multirow[t]{2}{*}{455} & \multirow[t]{2}{*}{ Rohde et al. (2007) } \\
\hline embPR & 5'-AGAAGTGCTCTAGCATCATCC-3' & & & \\
\hline
\end{tabular}

${ }^{1} \mathrm{~F}=$ forward; $\mathrm{R}=$ reverse.

was used as a strong biofilm control (Gill et al., 2005), and Staph. epidermidis strain ATCC 12228 was used as a weak biofilm control (Zhang et al., 2003). Each CNS isolate was tested on 3 independent days. Additionally, inocula were incubated at $37^{\circ} \mathrm{C}$ for $24 \mathrm{~h}$ and their growth was assessed visually. After $24 \mathrm{~h}$, growth appeared to be equal for all isolates and no slow-growing isolates were identified.

\section{DNA Isolation}

Genomic DNA was isolated as described by Arciola et al. (2001), with some modifications. Briefly, bacteria from $1.5 \mathrm{~mL}$ of overnight culture were harvested by centrifugation. The pellets were resuspended in a lysostaphin solution $[0.1 \mathrm{mg} / \mathrm{mL}$ (Sigma, St. Louis, $\mathrm{MO}$ ) in Milli-Q water (EMD Millipore, Billerica, MA)] and incubated for $30 \mathrm{~min}$ at $37^{\circ} \mathrm{C}$. A volume $(150 \mu \mathrm{L})$ of proteinase $\mathrm{K}$ solution $(0.1 \mathrm{mg} / \mathrm{mL}$ of proteinase $\mathrm{K}$ (Sigma) in $0.1 M$ Tris- $\mathrm{HCl} \mathrm{pH} 7.5,1 \mathrm{mM} \mathrm{CaCl}{ }_{2}$ ) was added and the mixture was incubated for $10 \mathrm{~min}$ at $37^{\circ} \mathrm{C}$. The samples were then heated for $5 \mathrm{~min}$ at $100^{\circ} \mathrm{C}$. Cells and insoluble debris were settled by centrifugation and supernatants were transferred to new tubes.

\section{Detection of icaA, aap, bap, fbe, embP, and atIE by PCR}

The presence of $i c a A, a a p, b a p, f b e, e m b P$, and atlE were detected with primers (Table 1 ) described previously (Cucarella et al. 2004; Rohde et al. 2005, 2007). Briefly, the typical PCR mixture $(50 \mu \mathrm{L})$ was composed of $200 \mathrm{ng}$ of genomic DNA, $0.2 \mathrm{~m} M$ deoxynucleotide 5 '-triphosphate, $1.5 \mathrm{mM} \mathrm{MgCl} 2,0.5 \mu M$ forward primer, $0.5 \mu M$ reverse primer, $5 \mu \mathrm{L}$ of $10 \times \mathrm{PCR}$ reaction buffer, 1.25 U of Taq DNA polymerase (GE Healthcare,
Waukesha, WI), and water (to $50 \mu \mathrm{L}$ ). The PCR mixtures were subjected to 5 min at $94^{\circ} \mathrm{C}, 30$ cycles of 30 s at $94^{\circ} \mathrm{C}, 30 \mathrm{~s}$ at $54^{\circ} \mathrm{C}$ for aap, $57^{\circ} \mathrm{C}$ for icaA and bap or $47^{\circ} \mathrm{C}$ for fbe, embP, and atlE, and $30 \mathrm{~s}$ at $72^{\circ} \mathrm{C}$, and a final $1 \mathrm{~min}$ at $72^{\circ} \mathrm{C}$ using a thermocycler. Genomic DNA from Staph. epidermidis strain ATCC 35984 was a positive control for $i c a A$, aap, fbe, embP, and atlE. For bap, genomic DNA from Staph. aureus strain V329 (Cucarella et al., 2004) was used as the positive control. For a negative control, sterile water was used instead of DNA. Samples were considered PCR positive when the amplicon size was equal to the positive control. Additionally, some PCR products were sent for sequencing to verify the identity of the amplicon.

\section{Amplification of the Variable Region of aap}

The length of the variable region of aap was measured as described before (Rohde et al., 2005). Briefly, the typical PCR mixture $(50 \mu \mathrm{L})$ was composed of $200 \mathrm{ng}$ of genomic DNA, $0.2 \mathrm{mM}$ deoxynucleotide 5 '-triphos-

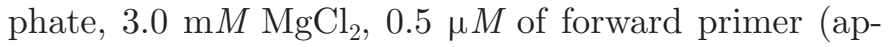
plongF; Table 1), $0.5 \mu M$ of reverse primer (applongR), $10 \mu \mathrm{L}$ of $5 \times$ Phusion GC buffer (New England Biolabs, Ipswich, MA), $1.25 \mathrm{U}$ of Phusion High Fidelity DNA polymerase (New England Biolabs), and water (to 50 $\mu \mathrm{L}$ ). The PCR mixtures were subjected to $5 \mathrm{~min}$ at $98^{\circ} \mathrm{C}, 30$ cycles of $10 \mathrm{~s}$ at $98^{\circ} \mathrm{C}, 10 \mathrm{~s}$ at $60^{\circ} \mathrm{C}$ and $2 \mathrm{~min}$ at $72^{\circ} \mathrm{C}$, and a final 5 min at $72^{\circ} \mathrm{C}$ using a thermocycler. Genomic DNA from Staph. epidermidis strains ATCC 35984 and ATCC 12228 were used as positive controls. For a negative control, sterile water was used.

\section{Dispersion of Biofilms by Enzymatic Treatments}

A biofilm dispersion assay was performed as described previously (Izano et al., 2007). A total of 30 
isolates representing each species and genotype were selected for this assay. Briefly, biofilms were grown as described in the Microtiter Biofilm Assay section, and after the 24-h incubation, $50 \mu \mathrm{L}$ of DNase I $(500 \mu \mathrm{g} /$ $\mathrm{mL}$ in $\left.150 \mathrm{~m} M \mathrm{NaCl}, 1 \mathrm{mM} \mathrm{CaCl})_{2}\right), 50 \mu \mathrm{L}$ of dispersin B $(100 \mu \mathrm{g} / \mathrm{mL}$ in PBS; Kane Biotech Inc., Winnipeg, $\mathrm{MB}$, Canada), or $50 \mu \mathrm{L}$ of proteinase $\mathrm{K}(500 \mu \mathrm{g} / \mathrm{mL}$ in $50 \mathrm{mM}$ Tris- $\mathrm{HCl} \mathrm{pH} 7.5,1 \mathrm{mM} \mathrm{CaCl} 2$ ) was added directly to the biofilms. Control wells were treated with $50 \mu \mathrm{L}$ of the buffer without the enzyme. Wells treated with dispersin $\mathrm{B}$ were incubated for $5 \mathrm{~min}$ at $37^{\circ} \mathrm{C}$, and those treated with proteinease $\mathrm{K}$ or DNase I were incubated for $1 \mathrm{~h}$ at $37^{\circ} \mathrm{C}$. After the treatments, the biofilms were treated as described in the Microtiter Biofilm Assay section.

\section{Confocal Laser Scanning Microscopy}

Biofilms were prepared as described in the Microtiter Biofilm Assay section but were stained with the FilmTracer FM 1-43 (Invitrogen, Eugene, OR), the FilmTracer LIVE/DEAD Biofilm Viability Kit (Invitrogen), wheat-germ agglutinin (WGA) conjugated with Oregon green (Invitrogen), BOBO-3 (Invitrogen), or the FilmTracer SYPRO Ruby Biofilm Matrix Stain (Invitrogen), as prescribed by the manufacturer. According to the manufacturer, WGA will bind to $\mathrm{N}$ acetyl-D-glucosamine and $N$-acetylneuraminic acid residues, BOBO-3 is a cell-impermeable DNA stain, and SYPRO Ruby stain labels most classes of proteins. The stained biofilms were visualized by confocal laser scanning microscopy (CLSM; FV1000 IX81; Olympus, Markham, ON, Canada) and images were acquired using Fluoview software (Olympus).

\section{Statistical Analysis}

After a normality check (and eventually data transformation), a linear mixed model was used to investigate biofilm absorbance according to the CNS species. Because samples could be repeated within cows that were clustered within herd, a multilevel hierarchical model was implemented in $\mathrm{R}$ ( $\mathrm{R}$ Foundation for Statistical Computing, Vienna, Austria) with the package lme4 (Bates et al., 2011) and languageR (Baayen et al., 2008). The models with random effects for udder quarter, cow and herd, or only herd were compared between each other with the likelihood ratio test and the parametric bootstrap, together with improvement in the Akaike information criterion. A second set of models were developed by adding covariates to the previous model. The covariates added were genes (icaA, bap, aap, embP, fbe, atlE), the interactions between these 6 genes, DIM, lactation number, and the SCC (on a log scale). Backward stepwise covariate selection was made by comparison of the full model with the nested model in the same fashion as above, beginning with the interaction term. Species and genes were kept in the model whatever their significance. Multiple comparisons between species were run with the Tukey test (multcomp package; Hothorn et al., 2008).

\section{RESULTS}

\section{Biofilm-Formation Potential Among CNS Isolates}

The microtiter plate-based assay is a good tool to determine the potential of an isolate to form a biofilm. Based on the amount of safranin bound by the biofilm $\left(\mathrm{A}_{490}\right)$, the ability of a CNS isolate to form a biofilm was classified as negative $\left(\mathrm{A}_{490}<0.110\right)$, weak $(0.110$ $\left.<\mathrm{A}_{490}<0.500\right)$, moderate $\left(0.500<\mathrm{A}_{490}<1.500\right)$, or strong $\left(\mathrm{A}_{490}>1.500\right)$. The majority $(85.1 \%)$ of the isolates were able to form a biofilm, whereas a minority $(14.9 \%)$ were considered biofilm-negative isolates (Table 2). Among the biofilm-positive isolates, 36.4, 25.5 , and $23.1 \%$ were weak, moderate, and strong biofilm formers, respectively. Most Staph. xylosus isolates $(84 \%)$ were moderate to strong biofilm formers, whereas most Staph. epidermidis isolates (84.6\%) were biofilm negative or weak biofilm formers. This suggested that Staph. xylosus isolates have the highest ability to form biofilms and Staph. epidermidis isolates have the lowest ability to form biofilms.

The median value of all isolates of each species combined was also used to evaluate the ability of CNS to form biofilms. As with the categories above, Staph. xylosus had the highest median value for its isolates and Staph. haemolyticus has the second highest median value (Figure 1). This suggests that both Staph. xylosus and Staph. haemolyticus had the greatest ability to form biofilms. Staphylococcus epidermidis had the lowest median value (Figure 1). Again, this suggests that Staph. epidermidis isolates had the lowest ability to form biofilms.

\section{Distribution of Biofilm-Associated Genes Among CNS Isolates}

The majority $(224,87.8 \%)$ of the isolates were positive for at least 1 of the 6 genes, and only 31 isolates $(12.2 \%)$ were negative for all 6 genes (Table 2).

$\boldsymbol{i c a A}$. In total, 134 isolates $(52.5 \%)$ were positive for $i c a A$, and the distribution of icaA among species appeared to occur at similar frequencies $(\sim 50 \%)$. However, the presence of $i c a A$ might occur at a lower frequency in Staph. epidermidis (30.8\%). 
Table 2. Biofilm-formation potential and distribution of biofilm-associated genes among CNS species

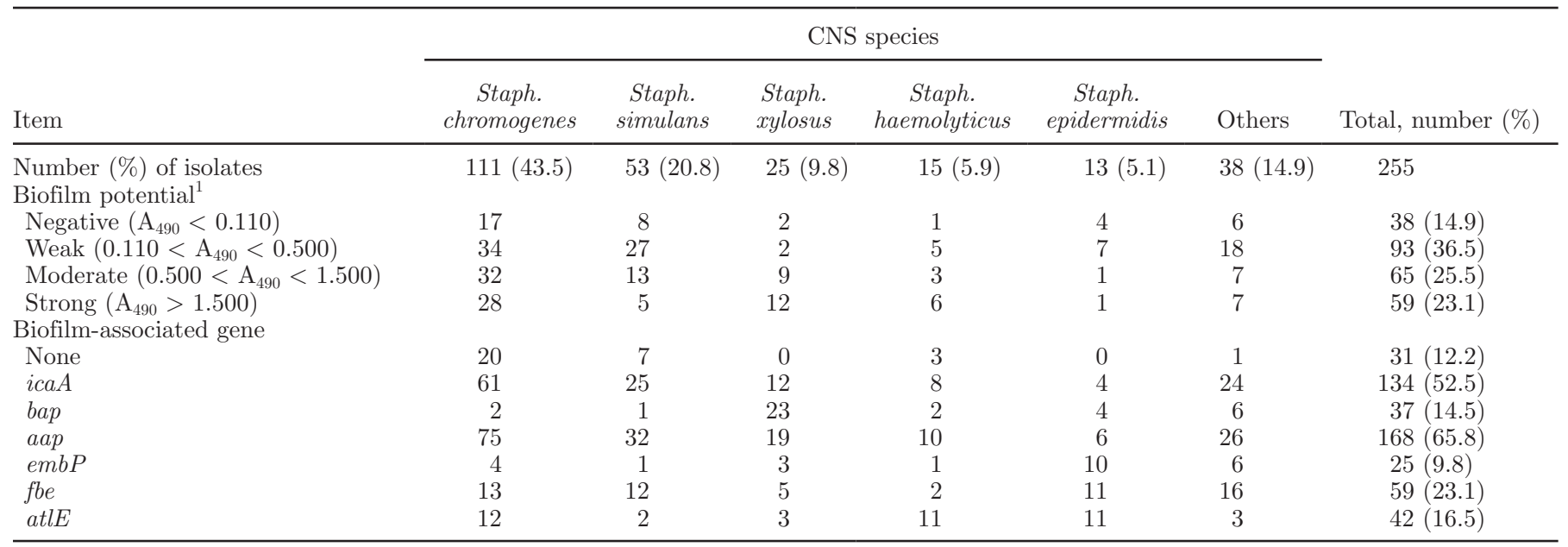

${ }^{1} \mathrm{~A}_{490}=$ absorbance at $490 \mathrm{~nm}$.

bap. Only 37 isolates $(14.5 \%)$ were bap positive, and the distribution of bap among CNS species varied considerably. The presence of bap in Staph. chromogenes and Staph. simulans isolates was rare. For Staph. haemolyticus and Staph. epidermidis, 13.3 and $30.8 \%$ of the isolates, respectively, were bap positive. The presence of bap was detected in almost every Staph. xylosus isolate $(92 \%)$.

$\boldsymbol{e m b P}$. The presence of $e m b P$ among CNS isolates was rare, and only $25(9.8 \%)$ isolates were positive. This gene was almost exclusively detected in Staph. epidermidis: $76.9 \%$ of these isolates were positive.

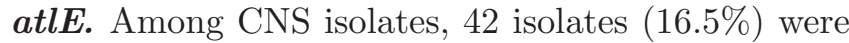
positive for atlE. This gene was mostly detected in 2 species, Staph. epidermidis (84.6\%) and Staph. haemolyticus $(73.3 \%)$.

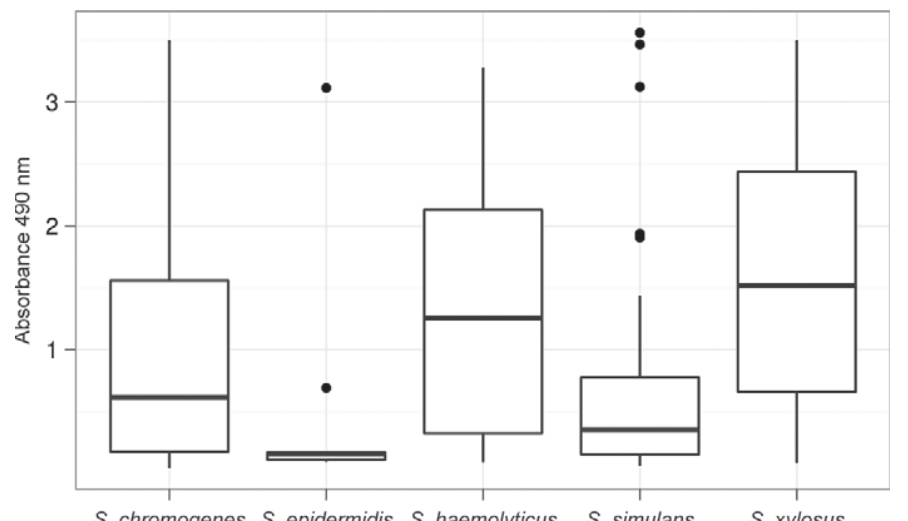

Figure 1. Biofilm strength for the dominant CNS species [Staphylococcus chromogenes $(\mathrm{n}=99)$, Staphylococcus epidermidis $(\mathrm{n}$ $=11)$, Staphylococcus haemolyticus $(\mathrm{n}=14)$, Staphylococcus simulans $(\mathrm{n}=50)$, Staphylococcus xylosus $(\mathrm{n}=24)]$. Points outside the box and whiskers are considered outliers. fbe. Compared with embP, bap, and atle, fbe was more frequently detected in isolates (23.1\%). Again, fbe was almost exclusively in Staph. epidermidis, with $84.6 \%$ of these isolates being positive.

aap. A total of 168 isolates, which is a majority $(65.8 \%)$, were aap positive, and the distribution of aap among species appeared to occur at similar frequencies $(\sim 65 \%)$. However, the presence of aap might occur at a lower frequency in Staph. epidermidis (46.2\%). Attempts to amplify the variable region of app failed for most of the aap-positive isolates (89.9\%) and appeared to be successful for 17 isolates. When amplification was successful, most isolates appeared to have 1,2 , or 3 repeats in the variable region, and only 1 isolate appeared to have 8 repeats. No trends were noted between the length of the aap repeats and biofilm formation.

Gene Combination. Among isolates that were positive for 1 of the 6 genes, 71 isolates $(27.8 \%)$ had only 1 of the 6 genes (Supplemental Tables 1 and 2). Unlike $i c a A$, bap, aap, and fbe, the genes embP and atlE were never detected alone and were always observed in combination with another gene. Most isolates $(60 \%)$ had at least 2 genes, and 84 of those isolates $(32.9 \%)$ had a 2 -gene combination, $55(21.6 \%)$ had a 3 -gene combination, $9(3.5 \%)$ had a 4 -gene combination, $4(1.6 \%)$ had a 5 -gene combination, and 1 isolate of Staph. epidermidis $(0.4 \%)$ had all 6 genes (Supplemental Tables 1 and 2). Staphylococcus simulans isolates were the only species in which a 3-gene combination was the largest combination observed. The combination most frequently observed was icaA-aap (86 isolates), and 55 of those were not combined with another gene. The most common triplet was the icaA-aap-atlE combination, and it was detected in 18 isolates. This triplet was almost exclusively found in 2 species, Staph. chromogenes (9 
isolates) and Staph. haemolyticus (6 isolates). The combination icaA-bap-aap was the second most common triplet (17 isolates), but it appeared almost exclusively in Staph. xylosus (9 isolates). The third most common triplet, with 16 isolates, was the icaA-aap-fbe combination, and it was mostly observed in Staph. chromogenes (6 isolates). The embP-fbe-atlE combination was the fourth most common triplet (14 isolates), but it was almost exclusively observed in Staph. epidermidis (10 isolates). Half of the embP-fbe-atlE-positive Staph. epidermidis isolates had 1, 2, or 3 of the other genes (bap, $i c a$, or aap).

\section{Biofilm Matrix Composition of Selected CNS Isolates}

To study the biofilm matrix composition of the CNS isolates, 30 isolates representing different biofilm phenotypes and genotypes were selected for enzymatic digestion of the matrix. Among the selected strains, some isolates were dispersed by dispersin B or DNase I, and most were dispersed by proteinase $\mathrm{K}$ (data not shown). This suggested most CNS isolates have a protein-based matrix and a few have a PNAG-based matrix.

To further characterize the biofilm matrix, 1 strong biofilm former and 1 weak biofilm former of each dominant species were selected for more tests. When the biofilms of the strong biofilm formers were treated with enzymes, none of the isolates was sensitive to the dispersin $\mathrm{B}$ treatment (Figure 2A), all isolates were sensitive to the proteinase $\mathrm{K}$ treatment (Figure $2 \mathrm{~B}$ ), and 2 of the 5 isolates were sensitive to the DNase treatment (less than $75 \%$ of the biofilm remained after treatment; Figure 2C). Only the biofilms of Staph. chromogenes and Staph. xylosus were sensitive to the DNase I treatment. For the weak biofilm formers, 3 of the 5 isolates were sensitive to the dispersin B treatment, 4 of the 5 isolates were sensitive to the proteinase $\mathrm{K}$ treatment, and all isolates were sensitive to the DNase I treatment (data not shown). Staphylococcus simulans and Staph. epidermidis were resistant to the dispersin B treatment, whereas Staph. haemolyticus was resistant to the proteinase K treatment. Again, this suggested that proteins and extracellular DNA (eDNA) play a larger role than PNAG in CNS biofilm formation.

To further study the composition of the matrix, CLSM was performed with several fluorescent stains that have different purposes, such as evaluating the amount of bacteria in the biofilm. The stain FM 1-43 integrates into the membrane of bacteria, and this helps in evaluating the number of cells and the general morphology of the biofilm. With the exception of the Staph. epidermidis isolate, biofilm morphology and the amount of bacteria were fairly similar (Figure 3). The biofilm of Staph. epidermidis appeared to be composed of several clusters or microcolonies (Figure 3). The LIVE/DEAD kit is composed of 2 stains, 1 (SYTO-9) that binds DNA in cells with intact cell membranes (viable) and 1 (propidium iodide) that binds DNA in cells with damaged cell membranes (dead). According to these stains, the Staph. simulans, Staph. epidermidis, and Staph. haemolyticus biofilms had a larger number of dead cells than did the Staph. chromogenes and Staph. xylosus biofilms (Figure 3). Wheat-germ agglutinin binds to $\mathrm{N}$-acetyl-D-glucosamine and $\mathrm{N}$-acetylneuraminic acid residues, and WGA is used to indicate the presence of PNAG in the biofilm matrix. The other stains used are specific for biofilm matrix components, such as proteins (SYPRO Ruby) and eDNA (BOBO-3). The biofilms of all isolates were bound by WGA, BOBO3, and SYPRO Ruby, which suggests that the biofilm matrix contains PNAG, eDNA, and proteins (Figure 3). For Staph. simulans, Staph. xylosus, and Staph. haemolyticus, the amounts of $\mathrm{N}$-acetyl-glucosamine polymer in their biofilms appeared to be similar; Staph. chromogenes appeared to have the lowest amount of PNAG, whereas Staph. epidermidis appeared to have the largest amount of PNAG (Figure 3).With regard to the amount of protein, the Staph. simulans and Staph. epidermidis isolates appeared to have the largest amounts of proteins in their biofilm matrix (Figure 3). Although BOBO-3 is a membrane-impermeable DNA stain and does not penetrate bacterial cells with intact cell membranes, it stains eDNA and may stain DNA inside cells with a compromised cell membrane. For eDNA, the relative number of dead cells stained with propidium iodide must be taken into account when evaluating the quantity of eDNA (Seper et al., 2011). At first glance, the amount of eDNA appeared to be similar in all species; however, the Staph. simulans, Staph. haemolyticus, and Staph. epidermidis biofilms had large populations of damaged or dead cells. This suggests that the eDNA BOBO-3 stain could also bind DNA from damaged cells. On the basis of this interpretation, the Staph. chromogenes and Staph. xylosus isolates would have the largest amounts of eDNA. This correlates well with the DNase treatment because the biofilms of Staph. chromogenes and Staph. xylosus were the only isolates sensitive to the treatment (Figure 2C).

Similar CLSM experiments were done for some negative, weak, and moderate biofilm formers to confirm observations from the microtiter plate assay. When the stain FM 1-43 was used, moderate biofilm formers had fewer cells than the strong biofilm formers but had substantially more cells than the weak or negative biofilm formers (data not shown). For the negative biofilm formers, scattered individual cells were observed, which suggests minimum binding to the substrate (data not shown). When WGA staining was positive, the stain 
was mainly focused around individual cells in the case of negative and weak biofilm formers (data not shown). For moderate biofilm formers, the biofilm morphology revealed by the stain was similar to the morphology of the strong biofilm formers, but the amount of stain was lower (data not shown). With regard to protein staining (SYPRO Ruby) and eDNA staining (BOBO-3), the stains were mostly focused around individual cells in the case of negative and weak biofilm formers, as observed with WGA staining (data not shown). Moderate biofilm formers were not stained with SYPRO Ruby and BOBO-3.

\section{Statistical Analysis}

To find relevant links between the data gathered by this study and data accumulated in the CBMRN database, statistical analyses were performed. For the purpose of statistical analysis, isolates identified as Staph. chromogenes, Staph. simulans, Staph. xylosus, Staph. haemolyticus, and Staph. epidermidis with the strongest confidence level were kept. After this round of elimination, 209 isolates were left for the analysis. The sample size was further restricted by eliminating isolates that came from composite samples when the isolate from the same cow was present in a quarter sample and the sampling was done on the same day. After this second round, 9 composite samples that were already sampled as quarter samples were removed and 198 isolates were used for our statistical analyses. Taking multiple comparisons into account, Staph. xylosus had a greater ability to form biofilm than did Staph. epidermidis and Staph. simulans, as well as Staph. chromogenes versus Staph. simulans, Staph. epidermidis versus Staph. haemolyticus, and Staph. haemolyticus versus Staph. simulans (Table 3). However, the effect was confounded by the genes harbored by each species (Table 4). The presence of $i c a A$, bap, or fbe was predicted to have a positive effect on biofilm formation, whereas the presence of $e m b P$ was predicted to have a negative effect on biofilm formation (Table 4). The presence of aap or atlE was predicted to have no significant effect on biofilm formation (Table 4). The combination of multiple genes was associated with a greater ability to form a biofilm, with the triplet $i c a A$ bap-aap and the pair icaA-aap being strong predictors of biofilm formation. Furthermore, biofilm formation was significantly increased when 4 or more genes were present. This suggests that a doselike response occurred with respect to the number of genes and biofilm formation (data not shown).

It is interesting that a strong relationship between the strength of a biofilm and the DIM was noted (Table 4 ), and it appears that CNS isolated later in the lacta-
A
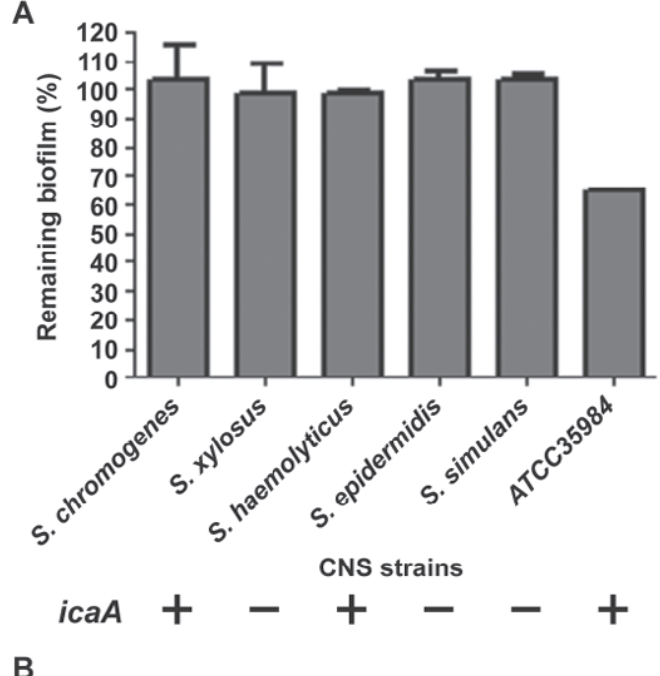

B
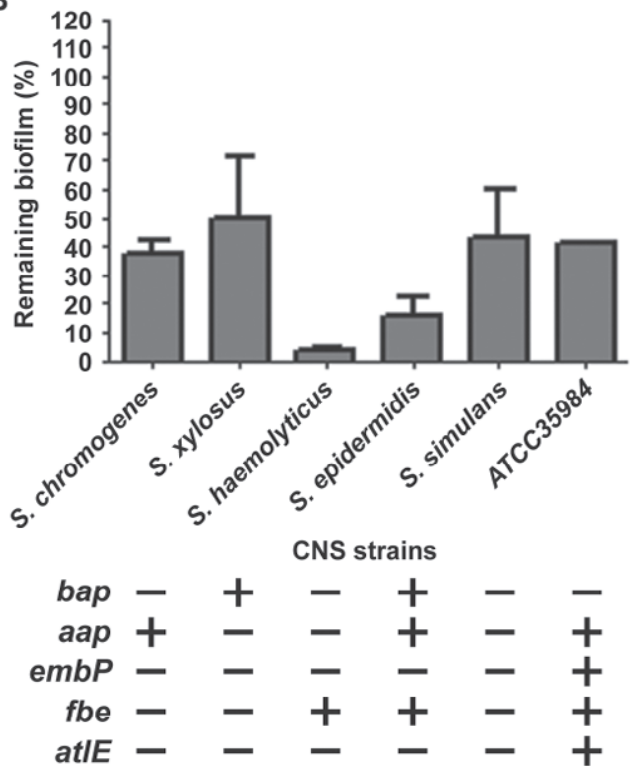

C

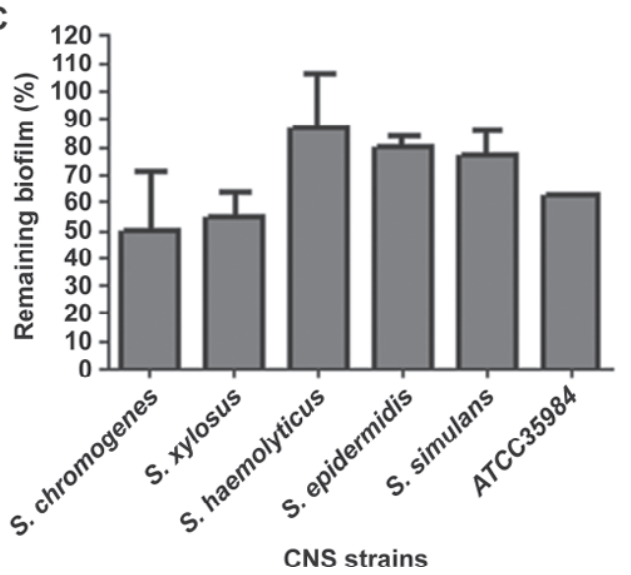

Figure 2. Dispersion of the CNS biofilms by (A) dispersin B (Kane Biotech Inc., Winnipeg, MB, Canada), (B) proteinase K, and (C) DNase I. The bar represents the results from 1 isolate. Genotype of the strain used for the dispersion assay is indicated under the graph. Staphylococcus epidermidis strain ATCC 35984 was used as a control because its biofilm is dispersed by all 3 enzymes. 


\section{S. chromogenes}

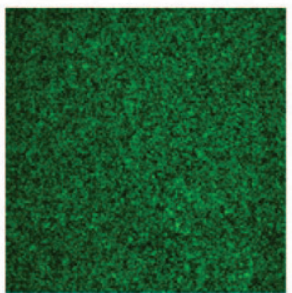

FM 1-43

(Cells)

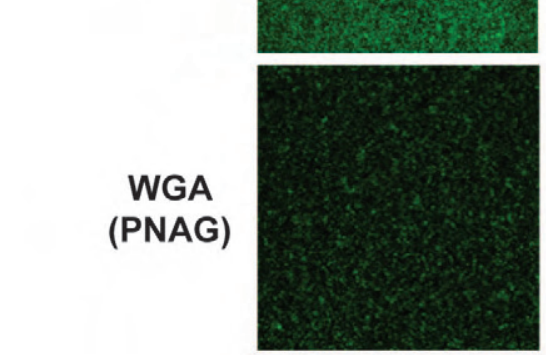

SYPRO Ruby (proteins)

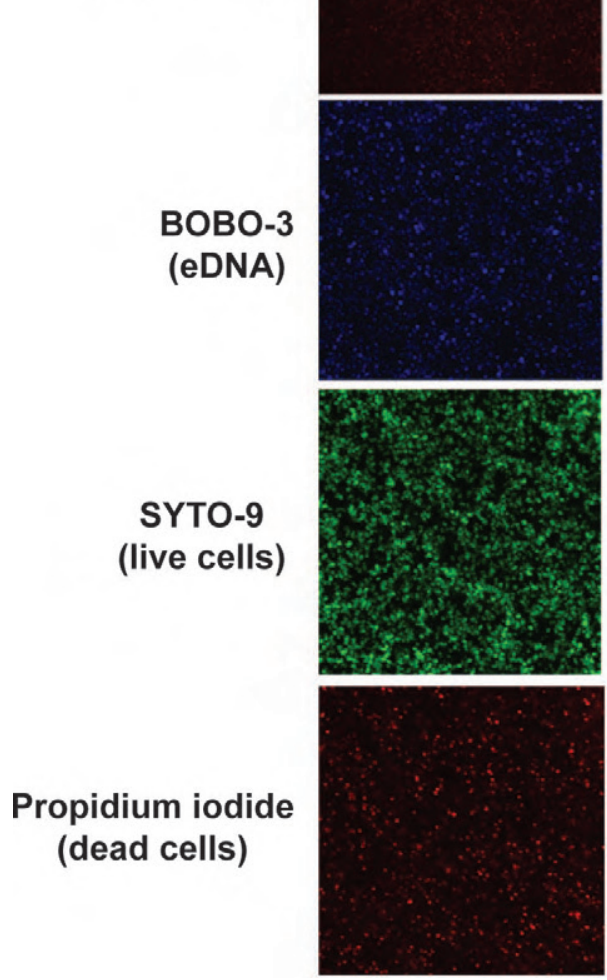

S. simulans
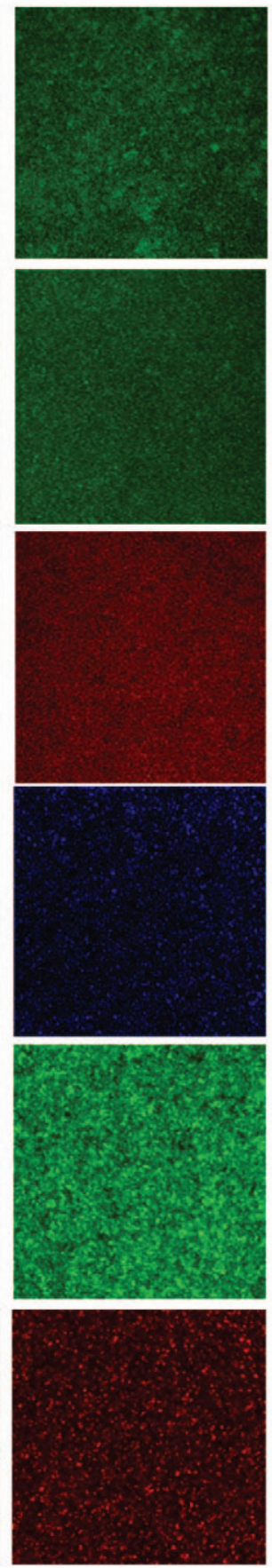

S. xylosus
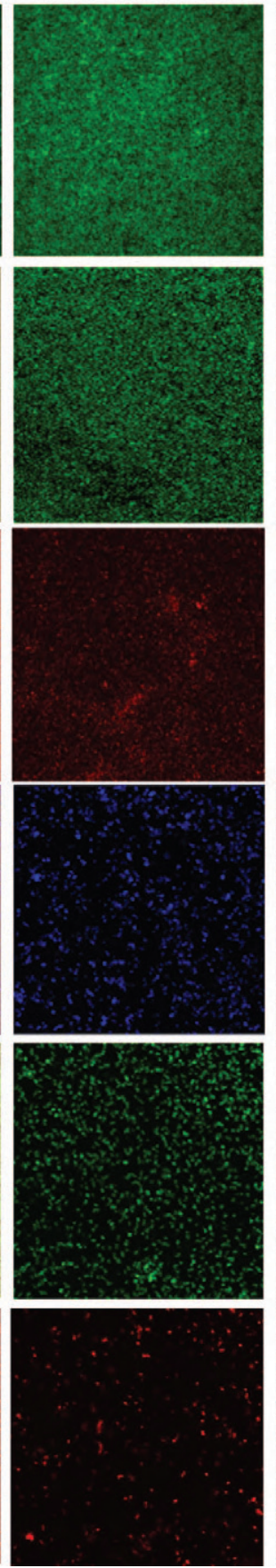

S. haemolyticus
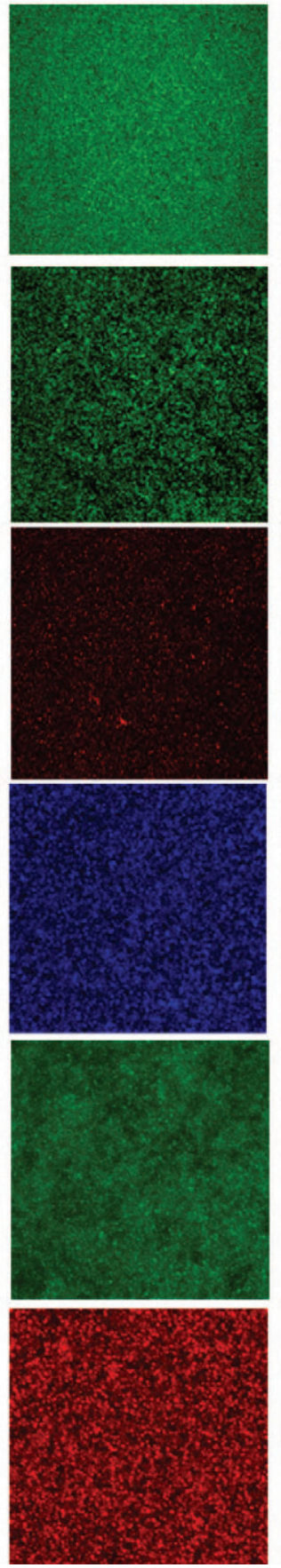

S. epidermidis
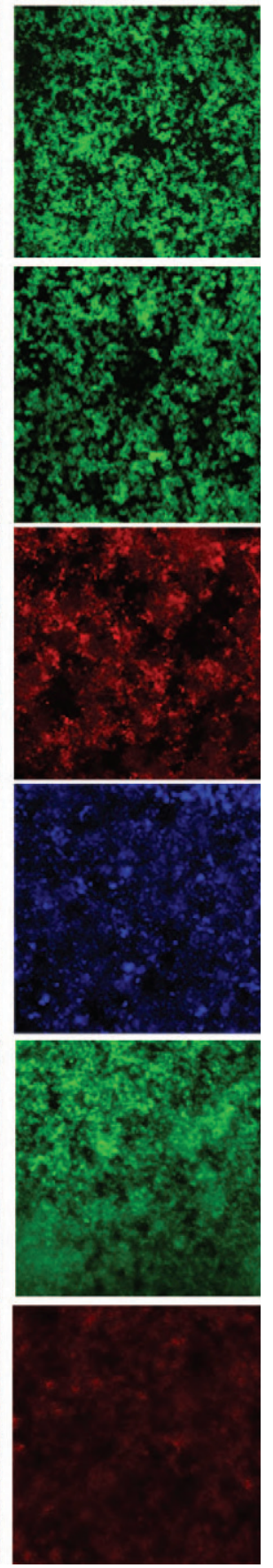

Figure 3. Confocal laser scanning microscopy of CNS biofilms stained with FM 1-43, BOBO-3, wheat-germ agglutinin (WGA)-Oregon green, SYPRO Ruby, SYTO, and propidium iodide (all from Invitrogen, Eugene, OR). PNAG = poly- $N$-acetyl glucosamine; eDNA $=$ extracellular DNA. Color version available in the online PDF.

tion cycle had a greater ability to form biofilms than did those isolated earlier in the lactation cycle. However, species were not evenly distributed across DIM. Additionally, no association between biofilm and SCC or parity was observed in the statistical model (Table 4). Overall, DIM and gene combinations are predicted to be the variables with the strongest effect on biofilm formation.

\section{DISCUSSION}

Biofilm formation is critical for the virulence of several pathogens and has also been proposed as an impor- 
Table 3. Multiple comparison of $\log ($ biofilm production +1$)$ between species in the first model

\begin{tabular}{lrrrl}
\hline Item & Estimate & SE & t-value & $P$-value \\
\hline Staphylococcus chromogenes vs. & & & & \\
$\quad$ Staphylococcus epidermidis & -0.389 & 0.145 & -2.676 & 0.053 \\
Staphylococcus haemolyticus & 0.138 & 0.121 & 1.145 & 0.77 \\
Staphylococcus simulans & -0.222 & 0.078 & -2.860 & 0.031 \\
Staphylococcus xylosus & 0.260 & 0.099 & 2.632 & 0.059 \\
Staph. epidermidis vs. & & & & \\
Staph. haemolyticus & 0.527 & 0.179 & 2.942 & 0.024 \\
Staph. simulans & 0.167 & 0.153 & 1.094 & 0.80 \\
Staph. xylosus & 0.648 & 0.164 & 3.942 & 0.001 \\
Staph. haemolyticus vs. & -0.360 & 0.130 & -2.764 & 0.041 \\
Staph. simulans & 0.121 & 0.142 & 0.851 & 0.91 \\
Staph. xylosus & & & & \\
Staph. simulans vs. & 0.481 & 0.108 & 4.475 & $<0.001$ \\
Staph. xylosus & & & & \\
\hline
\end{tabular}

tant virulence factor for the mastitis pathogens Staph. aureus, E. coli, and Strep. uberis (Melchior, 2011). In the case of CNS, it has been established that biofilms play an important role in the virulence of Staph. epidermidis, especially for infections associated with indwelling medical devices (Otto, 2008). With the exception of Staph. epidermidis, information on the biofilm formation of other CNS species has been very limited and, in the case mastitis-associated CNS, is limited to 2 studies (Tormo et al., 2005; Simojoki et al., 2012). The objective of our study was to characterize the ability of CNS associated with mastitis to form biofilms.

The majority $(85.1 \%)$ of the isolates tested were biofilm positive, and a minority $(14.9 \%)$ were biofilm negative. Using a similar assay, Simojoki et al. (2012) observed the opposite: most mastitis-associated CNS were biofilm negative $(68.7 \%)$ and a minority of isolates were biofilm positive $(31.3 \%)$. The distribution of CNS species in both studies was similar, with the exception that Staph. xylosus was not reported as a separate group by Simojoki et al. (2012). In our study, we ob- served that the ability to form biofilms varied among CNS species and that Staph. haemolyticus and Staph. xylosus were strong biofilm formers and Staph. simulans and Staph. epidermidis were weak biofilm formers. Previous studies with human isolates demonstrated that most Staph. haemolyticus (53/72) and Staph. xylosus $(11 / 12)$ strains were able to form biofilms (Planchon et al. 2006; Fredheim et al., 2009). This supports our observation that Staph. haemolyticus and Staph. xylosus have strong biofilm-formation potential. Therefore, the distribution of CNS species in the sample tested likely influenced the percentage of biofilm formers and may offer an explanation for the difference observed between our study and that by Simojoki et al. (2012). Another potential reason for the discrepancy between our study and the study by Simojoki et al. (2012) is the media used (BHI vs. tryptic soy broth). Minor differences in media composition and source, such as the manufacturer, have an effect on biofilm formation, and this was previously observed for Staph. haemolyticus (Fredheim et al., 2009) and in our laboratory for the

Table 4. Effect of genes and selected covariates on $\log ($ biofilm +1$)$ in the linear mixed model

\begin{tabular}{lcccc}
\hline Gene and covariate & Estimate & $\mathrm{SE}$ & $t$-value & $\mathrm{MCMC}^{1} P$-value \\
\hline Intercept & 0.624 & 0.254 & 2.459 & 0.042 \\
Species & & & - & - \\
$\quad$ Staphylococcus chromogenes & Reference & - & -0.846 & 0.46 \\
Staphylococcus epidermidis & -0.149 & 0.176 & 1.378 & 0.10 \\
Staphylococcus haemolyticus & 0.175 & 0.127 & -1.730 & 0.072 \\
Staphylococcus simulans & -0.136 & 0.079 & -0.524 & 0.003 \\
Staphylococcus xylosus & -0.072 & 0.138 & 3.188 & 0.003 \\
Presence of icaA & 0.173 & 0.054 & 2.666 & 0.016 \\
Presence of bap & 0.333 & 0.125 & 1.030 & 0.043 \\
Presence of aap & 0.063 & 0.061 & -2.298 & 0.073 \\
Presence of embP & -0.306 & 0.133 & 0.001 \\
Presence of fbe & 0.119 & 0.089 & -1.437 & 0.46 \\
Presence of atle & -0.127 & 0.089 & -1.966 & \\
DIM & 0.001 & 0.000 & -1.261 & \\
SCC (log) & -0.023 & 0.019 & & \\
\hline
\end{tabular}

${ }^{1} \mathrm{MCMC}=$ Markov chain Monte Carlo. 
swine pathogen Actinobacillus pleuropneumoniae (Labrie et al., 2010).

In this study, we screened mastitis-associated CNS for genes associated with biofilm formation of Staph. epidermidis (Rohde et al., 2007). In the study by Simojoki et al. (2012), mastitis-associated CNS were screened for MSCRAMM (microbial surface components recognizing adhesive matrix molecules), which are traditionally associated with the adhesion and invasion of host cells and biofilm formation of Staph. aureus (Rohde et al., 2007; Otto, 2008; Heilmann, 2011). The common genes in both studies were $i c a A$ and bap. In our studies, 52.5 and $14.5 \%$ of the isolates were positive for $i c a A$ and bap, respectively. Simojoki et al. (2012) did not detect $i c a A$ or bap in their isolates. The difference between the amount of bap reported in this study and that by Simojoki et al. (2012) is likely linked to the CNS species included in both studies. In the study by Simojoki et al. (2012), Staph. xylosus was not reported as a separate group, and in the current study, the bap gene was predominantly detected in Staph. xylosus $(23 / 25)$ and was rarely detected in the other CNS species $(14 / 230)$. In support of our observation, Planchon et al. (2006) also observed a high percentage of Staph. xylosus isolated from human skin that was positive for bap by PCR $(9 / 12)$ or Southern blot $(12 / 12)$. Another reason for the discrepancy might be the primers used to amplify bap. Although the source for the primer design and the reverse primer was identical, the design for the forward primer was optimized by creating a degenerate primer and slightly shifting the position of the primer. To redesign the forward primer, the bap sequence from various CNS, which are deposited in GenBank (Tormo et al., 2005), were aligned with the primer sasp-6m (Cucarella et al., 2004) and a new primer was designed to decrease the number of mismatches. The source of the discrepancy between the number of icaA reported in this study and those reported by Simojoki et al. (2012) is probably the primers used to amplify icaA. Simojoki et al. (2012) used primers that were specific for Staph. aureus icaA, whereas we used primers specific for Staph. epidermidis icaA. The use of primers specific for Staph. epidermidis icaA is probably more suitable than primers based on Staph. aureus icaA for the detection of $i c a A$ in CNS. However, the icaA primers and PCR conditions used in our study may lack sensitivity. With CLSM, WGA detected PNAG in the biofilms of $i c a A$-negative isolates and, based on our experience, the relationship is good between WGA staining of a biofilm and PNAG production by bacteria. Therefore, WGA staining of $i c a A$-negative isolates suggests that these isolates are either $i c a A$ positive or produce a structure containing $\mathrm{N}$-acetyl-glucosamine. Such a phenomenon has also been observed in Staph. haemolyticus, an ica- negative human isolate that was stained with WGA (Fredheim et al., 2009).

The lack of sensitivity may not be limited to the icaA PCR and may extend to embP, atle, and fbe PCR. The primers used in those PCR are based on Staph. epidermidis, and those genes were detected in a larger proportion of Staph. epidermidis. However, embP, atlE, and fbe were detected in every species, suggesting that the PCR had good specificity and acceptable sensitivity. Furthermore, bifunctional autolysin can be used to differentiate staphylococci species (Albrecht et al., 2012) and subtype Staph. epidermidis (Sivadon et al., 2006). Therefore, a negative atle gene may indicate that an isolate possesses a different autolysin type. However, the sensitivity and specificity could not be fully assessed given the lack of genetic sequences (e.g., genome and genes) for CNS, with the exception of Staph. epidermidis. Therefore, strains with known sequence that may act as controls were lacking, and information on genomes of minor CNS would thus help improve the sensitivity of the PCR screens.

The icaA gene was present in roughly $50 \%$ of the isolates tested, and the biofilms of most CNS, including $i c a A$-positive isolates, were not detached by dispersin $\mathrm{B}$. The biofilms of some $i c a A$-negative isolates were also stained with WGA. This suggests that CNS associated with mastitis likely forms PNAG-independent biofilms and that PNAG plays a complementary role as a matrix component. Poly- $N$-acetyl glucosamine-independent biofilm formation has been observed in other staphylococci (Toledo-Arana et al., 2005; Frank and Patel, 2007; Qin et al. 2007). Given that PNAG does not appear to be a major component of the biofilm matrix, other molecules, such as eDNA and proteins, likely play a more important role. Extracellular DNA may act as cell-tosurface or cell-to-cell adhesins, or both (Whitchurch et al., 2002). Fluorescent staining and DNase treatment of CNS biofilms indicated eDNA is present in the biofilm matrix of CNS associated with mastitis. This has also been reported for human isolates of Staph. haemolyticus (Fredheim et al., 2009). Given that dispersion by DNase never exceeded $50 \%$, eDNA may play only a secondary role as a component of the biofilm matrix. The most significant dispersion was observed with proteinase Kinduced biofilm dispersion; 50 to $100 \%$ of the biofilm could be dispersed using this enzyme. Several proteins have been reported to play a role in Staph. epidermidis biofilms, including Bap, Aap, EmbP, Fbe, and AtlE. The Aap mediates intercellular adhesion and biofilm formation in Staph. epidermidis and it can act independently or cooperatively with the $i c a$ operon (Rohde et al., 2005). Additionally, Bap can mediate biofilm formation in the absence of PNAG in several Staphylococcus species (Tormo et al., 2005). It is likely, based on 
the distribution of bap, that biofilm formation in Staph. xylosus is Bap dependent. Furthermore, the presence of genes that would help mediate a protein-based biofilm was detected in very few isolates, with the exception of aap. Our statistical analysis indicates that some of the genes, such as bap, icaA, and aap, may interact to increase biofilm formation, thus indicating that polysaccharides and proteins are required for a strong biofilm despite the proteinaceous nature of the biofilm. However, some combinations were restricted to one species and, in some rare cases, the absence of the 6 genes tested was noted in strong biofilm formers. Therefore, uncharacterized proteins must mediate biofilm formation in most CNS. Proteinaceous biofilms formed with unknown proteins have also been reported for Staph. epidermidis (Qin et al., 2007) and Staph. haemolyticus (Fredheim et al., 2009). Furthermore, the protein-based biofilm formed by mastitis-associated CNS explains the poor relationship between biofilm formation and slime production observed previously for mastitis-associated CNS (Simojoki et al., 2012).

Biofilms are often associated with chronic and persistent infections (Costerton et al., 1999). It has been hypothesized that biofilms are involved in mastitis because $50 \%$ of the CNS IMI are persistent (Taponen et al., 2006). Previously, Simojoki et al. (2012) did not observe an association between biofilm formation and CNS IMI persistence and severity. We did not observe a relationship between biofilms and SCC; therefore, biofilms do not appear to affect CNS IMI severity. Unfortunately, the data available in the CBMRN database do not differentiate all CNS isolates at the species level; thus, a solid statistical model cannot be established to test whether an association exists between biofilm formation and persistent IMI. However, our statistical analysis did reveal a positive relationship between DIM and biofilm strength. This suggests that strong biofilm formers are selected for during lactation. The reason for such selection is unclear, but it is likely that biofilms increase the ability of CNS to persist in the intramammary environment. This indirectly indicates a relationship between biofilm formation and persistent IMI. Furthermore, the presence of biofilm-positive CNS at the onset of the dry-off period might have an effect on blanket dry-cow therapy, given that a biofilm increases bacterial resistance to antibiotics. A biofilmpositive isolate might survive blanket dry-cow therapy, and this could increase the probability of a recurrent CNS IMI in the lactation period. This hypothesis has yet to be tested.

Alternatively, the ability to form biofilms might facilitate the environmental transmission of CNS at a later stage of lactation. Piessens et al. (2011) consid- ered, based on a reservoir study, that Staph. xylosus is an environmental bacterium, Staph. chromogenes and Staph. epidermidis are host-adapted bacteria, and Staph. haemolyticus and Staph. simulans are pathogens that persist in the environment. In our sampling, Staph. xylosus was associated with the highest DIM values and was 1 of the 2 strongest biofilm formers among CNS species. Therefore, biofilms might help Staph. xylosus survive in the environment and facilitate its transmission from the farm environment to the intramammary environment when the cow is lactating. This hypothesis can also be applied to Staph. haemolyticus, given that it is the other strong biofilm former and that it can persist in the environment. Environmental biofilms have been shown to be important in the persistence of other bacterial pathogens, such as E. coli, Vibrio cholerae, and Legionella pneumophila (Cooper and Hanlon, 2010; Shikuma and Hadfield, 2010). The presence of environmental biofilms would require on-farm management to reduce the risk of infection. Recently, it has been demonstrated that the management of the cow's environment, such as bedding conditions or pasture access, has a positive outcome on CNS IMI incidence (Dufour et al., 2012).

\section{CONCLUSIONS}

Most CNS isolates from subclinical mastitis have the ability to form protein-based biofilms. Biofilm formation ability varied among CNS species, with Staph. $x y$ losus and Staph. haemolyticus having the highest ability to form biofilms. Biofilm formation was associated with the presence of specific gene combinations (icaA-bapaap and icaA-aap). Additionally, a strong positive association existed between DIM and biofilm strength.

\section{ACKNOWLEDGMENTS}

This research was supported from a grant by the Dairy Research Cluster [Dairy Farmers of Canada (Ottawa, ON, Canada), Agriculture and Agri-Food Canada (Ottawa, ON, Canada), Canadian Dairy Commission (Ottawa, ON, Canada)] through the Canadian Bovine Mastitis Research Network (Saint-Hyacinthe, Quebec, Canada). We also thank Sébastien Choinière for his technical assistance with some of the biofilm assays and Julie Santerre for help with the atlE, embP, and fbe PCR (both of Université de Montréal, St-Hyacinthe, QC, Canada). François Malouin (Université de Sherbrooke, Sherbrooke, QC, Canada) and Iñigo Lasa (Universidad Publica de Navarra, Pamplona, Spain) are also thanked for generously providing the Staph. epidermidis control strains and Staph. aureus strain V329, respectively. We 
also acknowledge Jenny-Lee Thomassin (McGill University, Montreal, QC, Canada) for proofreading the manuscript.

\section{REFERENCES}

Albrecht, T., S. Raue, R. Rosenstein, K. Nieselt, and F. Götz. 2012. Phylogeny of the staphylococcal major autolysin and its use in genus and species typing. J. Bacteriol. 194:2630-2636.

Andersen, S., I. R. Dohoo, R. Olde Riekerink, and H. Stryhn, and Mastitis Research Workers' Conference. 2010. Diagnosing intramammary infections: Evaluating expert opinions on the definition of intramammary infection using conjoint analysis. J. Dairy Sci. 93:2966-2975.

Arciola, C. R., S. Collamati, E. Donati, and L. Montanaro. 2001. A rapid PCR method for the detection of slime-producing strains of Staphylococcus epidermidis and S. aureus in periprosthesis infections. Diagn. Mol. Pathol. 10:130-137.

Baayen, R. H., D. J. Davidson, and D. M. Bates. 2008. Mixed-effects modeling with crossed random effects for subjects and items. J. Mem. Lang. 59:390-412.

Bates, D., M. Maechler, and B. Bolker. 2011. lme4: Linear mixedeffects models using S4 classes. Accessed Sep. 20, 2012. http:// cran.r-project.org/web/packages/lme4/index.html.

Christner, M., G. C. Franke, N. N. Schommer, U. Wendt, K. Wegert, P. Pehle, G. Kroll, C. Schulze, F. Buck, D. Mack, M. Aepfelbacher, and H. Rohde. 2010. The giant extracellular matrix-binding protein of Staphylococcus epidermidis mediates biofilm accumulation and attachment to fibronectin. Mol. Microbiol. 75:187-207.

Cooper, I. R., and G. W. Hanlon. 2010. Resistance of Legionella pneumophila serotype 1 biofilms to chlorine-based disinfection. J. Hosp. Infect. 74:152-159.

Costerton, J. W., P. S. Stewart, and E. P. Greenberg. 1999. Bacterial biofilms: A common cause of persistent infections. Science 284:1318-1322.

Cucarella, C., M. A. Tormo, C. Úbeda, M. P. Trotonda, M. Monzón, C. Peris, B. Amorena, I. Lasa, and J. R. Penadés. 2004. Role of biofilm-associated protein bap in the pathogenesis of bovine Staphylococcus aureus. Infect. Immun. 72:2177-2185.

Dohoo, I. R., J. Smith, S. Andersen, D. F. Kelton, S. Godden, and Mastitis Research Workers' Conference. 2011. Diagnosing intramammary infections: Evaluation of definitions based on a single milk sample. J. Dairy Sci. 94:250-261.

Dufour, S., I. R. Dohoo, H. W. Barkema, L. DesCôteaux, T. J. DeVries, K. K. Reyher, J.-P. Roy, and D. T. Scholl. 2012. Coagulase-negative staphylococci intramammary infection epidemiology. J. Dairy Sci. 95:3110-3124.

Frank, K. L., and R. Patel. 2007. Poly- $N$-acetylglucosamine is not a major component of the extracellular matrix in biofilms formed by icaADBC-positive Staphylococcus lugdunensis isolates. Infect. Immun. 75:4728-4742.

Fredheim, E. G. A., C. Klingenberg, H. Rohde, S. Frankenberger, P. Gaustad, T. Flægstad, and J. E. Sollid. 2009. Biofilm formation by Staphylococcus haemolyticus. J. Clin. Microbiol. 47:1172-1180.

Gill, S. R., D. E. Fouts, G. L. Archer, E. F. Mongodin, R. T. Deboy, J. Ravel, I. T. Paulsen, J. F. Kolonay, L. Brinkac, M. Beanan, R. J. Dodson, S. C. Daugherty, R. Madupu, S. V. Angiuoli, A. S. Durkin, D. H. Haft, J. Vamathevan, H. Khouri, T. Utterback, C. Lee, G. Dimitrov, L. Jiang, H. Qin, J. Weidman, K. Tran, K. Kang, I. R. Hance, K. E. Nelson, and C. M. Fraser. 2005. Insights on evolution of virulence and resistance from the complete genome analysis of an early methicillin-resistant Staphylococcus aureus strain and a biofilm-producing methicillin-resistant Staphylococcus epidermidis strain. J. Bacteriol. 187:2426-2438.

Heilmann, C. 2011. Adhesion mechanisms of staphylococci. Adv. Exp. Med. Biol. 715:105-123.

Heilmann, C., M. Hussain, G. Peters, and F. Gotz. 1997. Evidence for autolysin-mediated primary attachment of Staphylococcus epidermidis to a polystyrene surface. Mol. Microbiol. 24:1013-1024.
Hothorn, T., F. Bretz, and P. Westfall. 2008. Simultaneous inference in general parametric models. Biom. J. 50:346-363.

Hussain, M., M. Herrmann, C. von Eiff, F. Perdreau-Remington, and G. Peters. 1997. A 140-kilodalton extracellular protein is essential for the accumulation of Staphylococcus epidermidis strains on surfaces. Infect. Immun. 65:519-524.

Izano, E. A., H. Wang, C. Ragunath, N. Ramasubbu, and J. B. Kaplan. 2007. Detachment and killing of Aggregatibacter actinomycetemcomitans biofilms by dispersin B and SDS. J. Dent. Res. $86: 618-622$.

Jacques, M., V. Aragon, and Y. D. N. Tremblay. 2010. Biofilm formation in bacterial pathogens of veterinary importance. Anim. Health Res. Rev. 11:97-121.

Labrie, J., G. Pelletier-Jacques, V. Deslandes, M. Ramjeet, E. Auger, J. H. Nash, and M. Jacques. 2010. Effects of growth conditions on biofilm formation by Actinobacillus pleuropneumoniae. Vet. Res. 41:3.

Mack, D., W. Fischer, A. Krokotsch, K. Leopold, R. Hartmann, H. Egge, and R. Laufs. 1996. The intercellular adhesin involved in biofilm accumulation of Staphylococcus epidermidis is a linear $\beta-1,6$-linked glucosaminoglycan: Purification and structural analysis. J. Bacteriol. 178:175-183.

Melchior, M. B. 2011. Bovine mastitis and biofilms. Pages 205-222 in Biofilms and Veterinary Medicine. Vol. 6. Springer Series on Biofilms. S. L. Percival, D. C. Knottenbelt, and C. A. Cochrane, ed. Springer, New York, NY.

Mitchell. G., D. L. Séguin, A. E. Asselin, E. Déziel, A. M. Cantin, E. H. Frost, S. Michaud, and F. Malouin. 2010. Staphylococcus aureus sigma B-dependent emergence of small-colony variants and biofilm production following exposure to Pseudomonas aeruginosa 4-hydroxy-2-heptylquinoline- $N$-oxide. BMC Microbiol. 10:33.

Nilsson, M., L. Frykberg, J.-I. Flock, L. Pei, M. Lindberg, and B. Guss. 1998. A fibrinogen-binding protein of Staphylococcus epidermidis. Infect. Immun. 66:2666-2673.

Otto, M. 2008. Staphylococcal biofilms. Curr. Top. Microbiol. Immunol. 322:207-228.

Piessens, V., S. De Vliegher, B. Verbist, G. Braem, A. Van Nuffel, L. De Vuyst, M. Heyndrickx, and E. Van Coillie. 2012. Intra-species diversity and epidemiology varies among coagulase-negative Staphylococcus species causing bovine intramammary infections. Vet. Microbiol. 155:62-71.

Piessens, V., E. Van Coillie, B. Verbist, K. Supre, G. Braem, A. Van Nuffel, L. De Vuyst, M. Heyndrickx, and S. De Vliegher. 2011. Distribution of coagulase-negative Staphylococcus species from milk and environment of dairy cows differs between herds. J. Dairy Sci. 94:2933-2944.

Planchon, S., B. Gaillard-Martinie, E. Dordet-Frisoni, M. N. BellonFontaine, S. Leroy, J. Labadie, M. Hébraud, and R. Talon. 2006. Formation of biofilm by Staphylococcus xylosus. Int. J. Food Microbiol. 109:88-96.

Pyörälä, S., and S. Taponen. 2009. Coagulase-negative staphylococciemerging mastitis pathogens. Vet. Microbiol. 134:3-8.

Qin, Z., X. Yang, L. Yang, J. Jiang, Y. Ou, S. Molin, and D. Qu. 2007. Formation and properties of in vitro biofilms of ica-negative Staphylococcus epidermidis clinical isolates. J. Med. Microbiol. 56:83-93.

Rajala-Schultz, P., K. L. Smith, J. S. Hogan, and B. C. Love. 2006. Antimicrobial susceptibility of 5 mastitis pathogens from first lactation and older cows. Vet. Microbiol. 102:33-42.

Reyher, K. K., S. Dufour, H. W. Barkema, L. Des Coteaux, T. J. Devries, I. R. Dohoo, G. P. Keefe, J. P. Roy, and D. T. Scholl. 2011. The National Cohort of Dairy Farms - A data collection platform for mastitis research in Canada. J. Dairy Sci. 94:1616-1626.

Rohde, H., E. C. Burandt, N. Siemssen, L. Frommelt, C. Burdelski, S. Wurster, S. Scherpe, A. P. Davies, L. G. Harris, M. A. Horstkotte, J. K. Knobloch, C. Ragunath, J. B. Kaplan, and D. Mack. 2007. Polysaccharide intercellular adhesin or protein factors in biofilm accumulation of Staphylococcus epidermidis and Staphylococcus aureus isolated from prosthetic hip and knee joint infections. Biomaterials 28:1711-1720. 
Rohde, H., C. Burdelski, K. Bartscht, M. Hussain, F. Buck, M. A. Horstkotte, J. K. M. Knobloch, C. Heilmann, M. Herrmann, and D. Mack. 2005. Induction of Staphylococcus epidermidis biofilm formation via proteolytic processing of the accumulation-associated protein by staphylococcal and host proteases. Mol. Microbiol. 55:1883-1895.

Sampimon, O., H. W. Barkema, I. Berends, J. Sol, and T. Lam. 2009. Prevalence of intramammary infection in Dutch dairy herds. J. Dairy Res. 76:129-136.

Seper, A., V. H. Fengler, S. Roier, H. Wolinski, S. D. Kohlwein, A. L. Bishop, A. Camilli, J. Reidl, and S. Schild. 2011. Extracellular nucleases and extracellular DNA play important roles in Vibrio cholerae biofilm formation. Mol. Microbiol. 82:1015-1037.

Shikuma, N. J., and M. G. Hadfield. 2010. Marine biofilms on submerged surfaces are a reservoir for Escherichia coli and Vibrio cholerae. Biofouling 26:39-46.

Simojoki, H., P. Hyvönen, C. Plumed Ferrer, S. Taponen, and S. Pyörälä. 2012. Is the biofilm formation and slime producing ability of coagulase-negative staphylococci associated with the persistence and severity of intramammary infection? Vet. Microbiol. 158:344-352.

Sivadon, V., M. Rottman, J.-C. Quincampoix, E. Prunier, P. de Mazancourt, L. Bernard, A. Lortat-Jacob, P. Piriou, T. Judet, and J.L. Gaillard. 2006. Polymorphism of the cell wall-anchoring domain of the autolysin-adhesin AtlE and its relationship to sequence type, as revealed by multilocus sequence typing of invasive and commensal Staphylococcus epidermidis strains. J. Clin. Microbiol. 44:1839-1843.

Supré, K., F. Haesebrouck, R. N. Zadoks, M. Vaneechoutte, S. Piepers, and S. De Vliegher. 2011. Some coagulase-negative Staphylococ- cus species affect udder health more than others. J. Dairy Sci 94:2329-2340

Taponen, S., H. Simojoki, M. Haveri, H. D. Larsen, and S. Pyorala. 2006. Clinical characteristics and persistence of bovine mastitis caused by different species of coagulase-negative staphylococci identified with API or AFLP. Vet. Microbiol. 115:199-207.

Tenhagen, B.-A., G. Koster, J. Wallmann, and W. Heuwieser. 2006. Prevalence of mastitis pathogens and their resistance against antimicrobial agents in dairy cows in Brandenburg, Germany. J. Dairy Sci. 89:2542-2551.

Toledo-Arana, A., N. Merino, M. Vergara-Irigaray, M. Debarbouille, J. R. Penades, and I. Lasa. 2005. Staphylococcus aureus develops an alternative, $i c a$-independent biofilm in the absence of the $\operatorname{arlRS}$ two-component system. J. Bacteriol. 187:5318-5329.

Tormo, M. A., E. Knecht, F. Gotz, I. Lasa, and J. R. Penades. 2005. Bap-dependent biofilm formation by pathogenic species of Staphylococcus: Evidence of horizontal gene transfer? Microbiology $151: 2465-2475$

Whitchurch, C. B., T. Tolker-Nielsen, P. C. Ragas, and J. S. Mattick. 2002. Extracellular DNA required for bacterial biofilm formation. Science 295:1487.

Zhang, Y. Q., S. X. Ren, H. L. Li, Y. X. Wang, G. Fu, J. Yang, Z. Q. Qin, Y. G. Miao, W. Y. Wang, R. S. Chen, Y. Shen, Z. Chen, Z. H. Yuan, G. P. Zhao, D. Qu, A. Danchin, and Y. M. Wen. 2003. Genome-based analysis of virulence genes in a non-biofilm-forming Staphylococcus epidermidis strain (ATCC 12228). Mol. Microbiol. 49:1577-1593. 